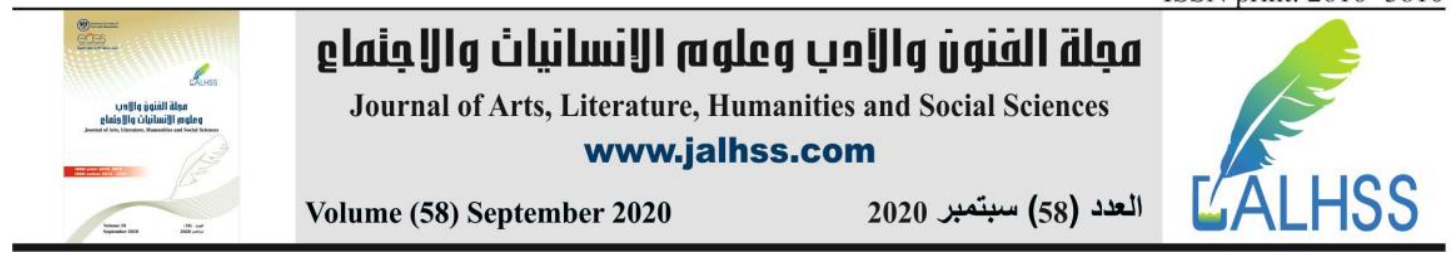

\title{
The Prophet Muhammad; A preacher and a social reformer
}

\author{
Professor Dr. Osama M. Abu Nahel \\ Professor of Modern and Contemporary History \\ Department of History, Faculty of Arts and Human Sciences \\ Al- Azhar University - Gaza (Palestine) \\ Email: osamabunahel@hotmail.com \\ osamabunahel@gmail.com
}

\begin{abstract}
When the Islamic call was revealed to the Prophet Muhammad the world in general, and the Arabian Peninsula in particular, was rife with political turmoil and social corruption. Consequently: the success of the Prophet Muhammad in his call did not come from a vacuum, but rather as a result of his effort and effort. Allah has given him the means and qualities that enabled him to make his call in the best way, and to bring him close to many of his tribe, and among the other tribes of the Arabian Peninsula.

Also, after his migration to Madinah, the Prophet Muhammad succeeded in establishing the first Islamic state, and he was able to melt the foundations of all Muslims in his crucible, and he was faithful in communicating his call, and was keen on the arrival of Islam to all people, as he planted in Muslims the highest verses of education and etiquette, in order to make From them and who will come after them a strong generation of faith in Allah, and through the knowledge through which they can master a large part of the world for a time. He also managed to unite the population of Madinah, both Muslim and non-Muslim, under his presidency, after he built the Prophet's Mosque, which served as a beacon to receive religious sciences, and a university to refine the morals and societal values that Arabs and non-Arabs lacked before the emergence of Islam.
\end{abstract}

Keywords: Prophet Muhammad, a Preacher, Social reformer, Makkah, Madinah. 


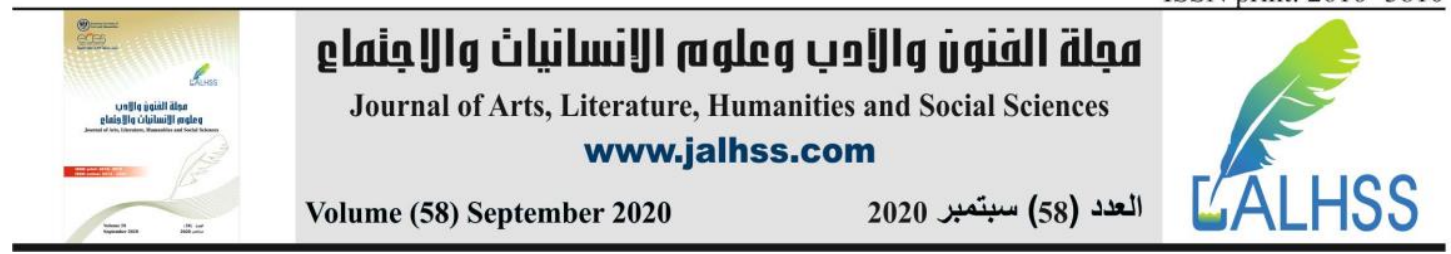

\section{Introduction}

The Prophet Muhammad was not only a prophet and a messenger; Rather, he was also a preacher and social reformer. His heavenly vocation emerged at a time when the world in general, and Arabia in particular, were filled with political turmoil and social corruption. In the Near East and Southern Europe regions, there were two empires Fighting between them (Persia and Byzantium), and the wars between them weakened them, the first because of their paganism, and the other, and despite their conversion to Orthodox Christianity, but their followers made Allah equals, as they made Jesus Christ, peace be upon him, as the son of Allah and Deify him. As for the Arabian Peninsula, political and social corruption has spread among its tribes due to its idolatry, and there are no longer prohibitions prohibiting their fighting among themselves for flimsy reasons without religious affiliation, or respect for the tribal traditions inherited between them.

All of this happened in a sprawling geographical area, until the date of the spiritual and human coup in the Near East region, with the emergence of the Islamic call and its missionary Muhammad Ibn Abdullah, to give the world a religious program that cancels what preceded it, and a new page in the history of humanity will be get started, and what will be folded Pages from before.

\section{The Importance of Study}

The importance of the study stems from the fact that it deals with a thorny and important subject at the same time which is closer to philosophy, as it touched upon the Call of the Prophet Muhammad, and the most important social reforms he undertook, at a time when social corruption spread in the Arab Peninsula and its surrounding non-Arab regions.

The Islamic call to move all humanity from darkness to light and guidance, thanks to the heavenly teachings that were revealed to the Prophet Muhammad; Persia was a hotbed of idolatry and the worship of fire without God, and the Byzantine Empire, even if it embraces Christianity as a tolerant heavenly law, but its rulers and followers from the peoples under its rule moved away from its grace, and the grace of the caller of Jesus Christ, as they made him a god without Allah from On the one hand, and moral and social disadvantages among the followers of the empire spread on the other hand; Hence the importance of this study.

Accordingly; The importance of the study stems from the fact that it is a philosophical study that deals with the method of calling (Da'wah) and the social reform path of the Prophet Muhammad, and that it will serve the studies of Islamic history and theological studies in the Islamic world and in the West.

\section{The study Problem}

The follower of the biography of the Prophet Muhammad as a preacher and social reformer, notes that the West, though he had studied and addressed this biography, but the writings of some western orientalists are still far from objective in dealing with this noble biography, and only sees it as the biography of a Bedouin man who quoted his call from the previous laws of his call Examples: Judaism and Christianity. The problem of the study is the following question: What role did the Prophet Muhammad play as a preacher and as a social reformer?

\section{Objectives of the study}

The study aimed to clarify the following:

1. The role of the Prophet Muhammad as a preacher.

2. The social reforms carried out by the Prophet Muhammad. 


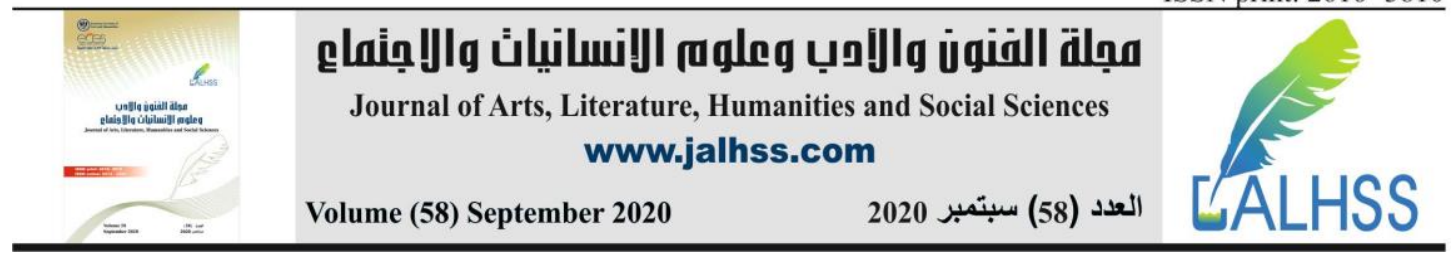

\section{Study Approach}

Because of its importance, the study relied on three approaches. The first: the historical approach that will assist us in the exploration of the primary information for the subject of our study, and the second: the descriptive analytical approach, to interpret and analyze that information to demonstrate its importance and scientific value, and the third: the comparative approach that will help us explain the differences between the nature of religious laws that existed when Islam emerged.

\section{Preface}

Life in most parts of the Arabian Peninsula was rough and harsh, with the exception of some urban areas. Like Yemen, Taif, etc. So, it's survived throughout history from falling under external colonialism, especially by the Persians and the Romans. The Islamic call was born at a time when social corruption prevailed in the Arab Peninsula and the surrounding non-Arab regions, and this call would not have succeeded and spread later in all parts of the world, had it not been for the choice of Allah Almighty for a person who differed in his upbringing and education from his peers in the Near East region, He is Muhammad ibn Abdullah, who has many good qualities; Such as honesty, faithfulness, and avoiding idolatry.

Islam, which the Prophet Muhammad called for, has had a profound impact on Arab society, both at the individual and group level. Islam moved the individual from sword to pacifism, from power to law, from revenge to retribution, from pornography to purity, from looting to honesty, from tribal life to personal responsibility, from paganism to monotheism ... etc. (Shalabi, Vol. 1, 1987: 558).

If we want to talk about Arab life and morals before the Islamic call; We notice the phenomenon of the spread of slavery in the Arabian Peninsula as in the rest of the world at that time, so when the Islamic call began, slaves entered Islam, and the Prophet Muhammad welcomed them. The conflict in the Arabian Peninsula was taking place for the slightest reasons, and tribal sovereignty prevailed and competition over it, as there was intense competition between Arab tribes for the presidency. And spread among the Arabs the principle of imitation of fathers, and follow their behavior in acts of worship and transactions and this principle was firmly in their hands, and finally spread among them the phenomenon of selling idols that were generating large sums of money from them (Shalabi, Vol. 1, 1987: 218-221). Among the most famous of these idols in the Arabian Peninsula, we find: Hubble, Lat, Uzza, and Manat, where the Almighty says: (Have ye seen Lat. and 'Uzza, and another, the third (goddess), Manat?) (Surah An-Najm: 19-20).

The Arabs had the habit that the victor in the wars of the tribes carried out the captivity of the conquered women, and it was the custom of the Arabs before Islam to polygamy without a known limit that ends, and they combined the two sisters, and they married the wife of their fathers if they divorced her or died from her. Obscene adultery was prevalent among the Arabs, and some of them were burying girls alive for fear of shame and spending, and killed children for fear of poverty. As for the relationship between the tribes, they were completely dismantled, and their forces were dedicated to wars. (al- Mubarakfory, 2007: 44-45)

With the increasing strength of the Islamic call in the Arabian Peninsula, history has turned the page of two empires that were the great powers in the meantime: the Persian Empire and the Byzantine Empire, and then the emergence of a new superpower has been announced that has a new spiritual and political taste beyond what preceded it, thanks to the strength of faith and belief that is With their followers, it is the Islamic state and its capital, Madinah, is led by 


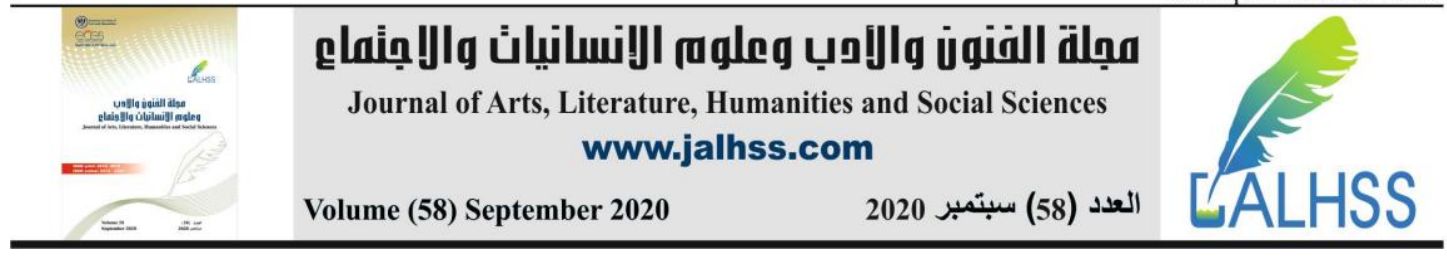

the Prophet Muhammad, and after him his best companions (As-Sahaba), may Allah be pleased with them all. Consequently: the emergence of the Islamic call and its missionary, the Prophet Muhammad, in the Near East region, has provided the entire world with a religious program that must precede the previous acts of worship, and a new page in the history of mankind will be started, and the pages before it will be folded.

After the beginning of the emergence of Islam, the peoples of the Persians and Byzantium had heard about this new religion, as they had heard about its victories in the Arabian Peninsula, they heard about his noble principles, and had heard about its tolerant principles, just as they had heard for the first time about a religion equal to the king and his subjects, and for the first time they heard about poor rulers patching their clothes, and fix their soles. while this happens next to them, they are living a life far removed from what is going on around them; Their countries are aging, and they have vanished, and their rulers have weakened them the rivalry over worldly authority, guided them extravagance, concern for their own affairs, and taxing their peoples with taxes. Their peoples were also weakened by religious and sectarian struggles that almost tore apart the unity of their states, such as the Byzantine Empire, where all those without the creed of the emperor were persecuted, in addition to the tyranny and oppression of emperors. The soldier knew that he was defending a lost cause that he had no right to; Byzantine armies - for example - are mostly mercenaries who are not bound by a system; They were defending a homeland owned by the gentlemen, and the emperors enjoyed it. So why do they give themselves up? Thus: Why do they shed their blood for him? They fight without a real desire to support their rulers. (Shalabi, Vol. 1, 1987: 586; al-Adawi, 1987-1988: 16; al-Selaby, 2006: 13)

There was an enormous contradiction in the social life of the Byzantine Romans, as religious tendency cemented in their minds, and monasticism spread throughout the Byzantine Empire, and the common man became involved in deep religious issues and Byzantine controversy. There was also a spread of all kinds of amusement and play, and mirth and luxury, and they loved violence and barbarism.

The Persian Empire was a larger and greater than the Byzantine Empire. Many deviant religions abound in it. Such as Zoroastrianism, Manicheanism, and Mazdakism that called for pornography in everything, which led to the spread of peasant revolutions, and the kings of Persia ruled hereditary, and placed themselves above all their subjects, because they considered themselves to be descendants of the gods, and the country's resources became the property of these kings, until many The farmers had their work, and they also spread the principle of the divine truth, by making the kings God's shadow on the earth and the gap between them and their peoples widened. (al-Selaby, 2006: 13-14)

The Persians and the Byzantines were always in a state of combat, and they alternated victory among themselves, but wars exhausted both the victor and the defeated. The Byzantine Empire was wide extending from the Levant to Egypt and ending with North Africa and the Iberian Peninsula; It thus includes many countries and many races, against whom the peoples subject to them have revolted against them from time to time. And if the Persian Empire extends its control over Iraq then, and imposes on its inhabitants its pagan religion and customs despite its Arabism. Religious persecution in Persia - and at that time was most severe, and the power of the Sassanids, which spanned nearly four centuries, was weakened, and their state became weak, and it should disappear. Although the inhabitants of Iraq resided in this control, but they did not agree with the formula of Persian colonization of their country; Therefore, they later - very much - welcomed the newly conquering Muslims of their country. (Shalabi, Vol. 1, 1987: 587) 


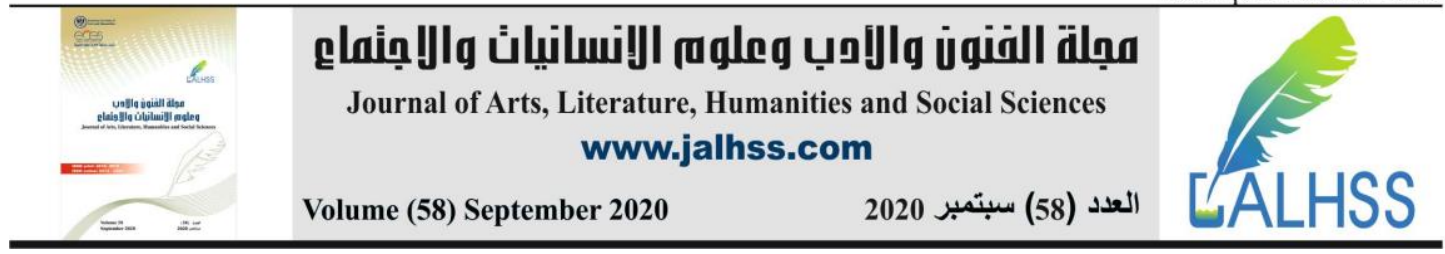

In general, Humanity, before the emergence of Islam was living in one of the lowest stages of human history, in its religious, economic, political and social affairs, and was suffering from general disorder in all affairs of its life, the pre-Islamic approach dominated beliefs and ideas, perceptions and souls, and ignorance and passion, dissolution and immorality, and coercion and abuse became among the most prominent features of the pre-Islamic approach that dominated humanity in all the world. (al-Selaby, 2006: 15)

From the foregoing, it becomes clear to us that before the emergence of the Islamic call the world in general and the Near East region in particular, was rife with all manifestations of religious turmoil, social and moral corruption. Consequently: it was necessary for a new heavenly call to appear in order to reform the conditions of mankind and return it to the straight path, and to convert again to faith in a religion that illuminates its dark path for long periods, so the call of the Prophet Muhammad was the guiding light for humanity's return to worship Allah Almighty.

\section{First: The role of the Prophet Muhammad as a prophet and a preacher}

Allah Almighty sent the prophets and messengers to their people in particular, and assigned them the most honorable of all functions, which is the call to worship Allah Almighty. They in turn passed it on to those who came after them whom Allah chose for this task, and the call to Allah comes in view of its importance in the second place after believing in Allah, the Almighty said: (And who is better in speech than one who invites to Allah and does righteousness and says, "Indeed, I am of the Muslims) (Surah Fussilat: 33). The call to worship Allah was of that magnificent rank, because of its great results. As guiding people, and guiding them to faith. The call to Allah is through call to his religion, walking on his path, following what he has ordered, and moving away completely from everything that enters polytheism in his worship, and getting closer to everything that Islam commanded, and moving away from everything that he forbade. (al-Qaradawi, 1996: 3)

Before the advent of the Islamic Call, the Prophet Muhammad was distinguished by sweet qualities and virtuous morals; So, The Prophet was the best of his people, chivalrous, the best of manners, the most recent of them, the most generous of them, the most righteous one, gave them a pledge, and their faithfulness to them, until his people called him "the Faithful", because of the good conditions and satisfactory qualities in him. (al- Mubarakfory, 2007: 6364)

\section{A. Definition of the call (da'wah)}

The call (da'wah) can be defined in language and term as follows:

1. The call (da'wah) in the language: From supplication, it is said: the individuals have joined together, i.e. they met, and it is said: He called for something, that is, urges and desires it; The call (da'wah) in language revolves around the meanings of question, demand, motivation, and enticement. The Prophet Muhammad, may Allah Almighty called, and the nation called for the unification and obedience of Allah. The word call (da'wah) was mentioned in the Holy Qur'an in different forms, and with multiple meanings as well. It came as a past tense as in the Almighty saying; (And who is better in speech than one who invites to Allah and does righteousness and says, "Indeed, I am of the Muslims) (Surah Fussilat: 33). came imperative verb as in the Almighty saying' (And the places of worship are for Allah (alone): So invoke not any one along with Allah) (Surah al-Jinn: 18), and came to do something as in the verse: (Invite (all) to the Way of thy Lord with wisdom and beautiful preaching; and argue with them in ways that are best and most gracious: for thy Lord knoweth best, who have strayed from His Path, and who receive guidance) (Surah An-Nahl: 125), and came as a infinitive in $\mathrm{n}$ the Almighty saying; (To Him is the Call of truth) (Surah al-Ra'd: 14), meaning Allah has his religion, which is Islam. 


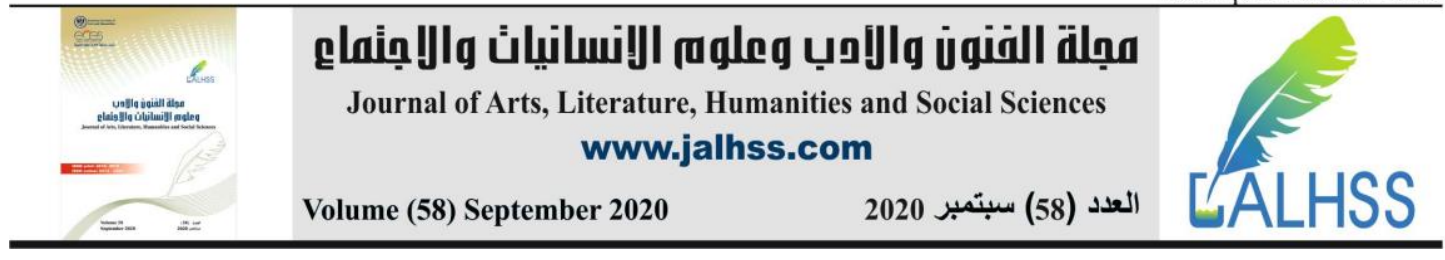

2. The call (da'wah) as a term: The call (da'wah) responded in more than one sense, as explained by more than one scholar. Ibn Taymiyyah defined it as the call to believe in Allah Almighty by believing, and the certainty of the pillars of faith, and the pillars of Islam, up to the level of charity, and it was defined as offering advice and guidance from those who are qualified for that in Every time and anywhere, in order to motivate people to Islam, and to warn them against others in accordance with ad hoc approaches, it was also defined as making an effort to spread the religion of Allah, and Muhammad al-Ghazali defined it as an integrated system that includes all cultures that guide people to the path of goodness. Allah Almighty says; (And keep thy soul content with those who call on their Lord morning and evening, seeking His Face). (Surah al-Kahf: 28)

Consequently: We can summarize the previous definitions, that the call itself is the delivery of Islam as a universal religion to all people, in all its aspects. Such as worship, interpersonal dealings, beliefs, morals, and behaviors.

\section{B. Definition of the preacher (da'i)}

The term the preacher (da'i) is called for whoever practices and performs the call (da'wah), either in Sharia. It is defined as the one who communicates Islam as a universal religion and teaches it to others, and works hard to implement it. the word of the preacher (da'i) can be applied to everyone who performs one of the actions of the call (da'wah), but whoever does all of it is the complete preacher (da'i), the Almighty said: (O Prophet! Truly We have sent thee as a Witness, a Bearer of Glad Tidings, and Warner, and as one who invites to Allah's (grace) by His leave, and as a lamp spreading light) (Surah al-Ahzab: 45-46). It can also be called the caller of every Muslim because the call to Allah is the function of all Muslims (alBayanouni, 2010: 40-41), the Almighty said: (Say thou: "This is my way: I do invite unto Allah, - on evidence clear as the seeing with one's eyes, - I and whoever follows me). (Surah Yusuf: 107)

Twenty-three years are the years of the Prophet Muhammad's call, in which it changed the face of history in the Arabian Peninsula. So, it's people melted in one crucible, and alienated it from the outmoded values that tore it apart, and replaced it with new values founded on justice, brotherhood and cohesion, and enabled it after this unity - and in its shadow - to overlook the outside world with a new sense, which wants to spread in all people the teachings of guidance and peace. (Ahmad, 1977: 19)

Many of the elite men and women of the Arabian Peninsula, especially from the Quraysh tribe, believed in the Prophet Muhammad throughout his call. Therefore, we must first define who is the companion (Sahabi). The elites of the Companions (As-Sahaba) of the Prophet wrapped around them, the disciples and took advantage of their abundant knowledge, that knowledge which they quoted from the teacher of humankind, Muhammad, peace be upon him. That is why many of them took on the title of science. Ali Ibn Abi Talib, the Prophet described him as the door to the city of science, given that the Messenger himself is that city mentioned. Abdullah Ibn Abbas, was described as the nation's Scholar for his asceticism and his superiority over his peers, and there is also Abdullah bin Amro Ibn al-Aas, who was nothing more than asceticism, knowledge and worship, and there are many companions (Sahaba) who enjoyed these characteristics and attributes, may Allah be pleased with them all.

The definition of the companionship is a language concomitance and subjugation, and as a term it is the one who met the Messenger, awake, believing him after his mission in his life, and he died on Islam. So, the companion (As-Sahabi) then. therefore, is the one who is long or shortened to sit with the Messenger, and whoever narrates it recently or does not narrate, and who has conquered with him or has not invaded, and who has seen a vision even if he 


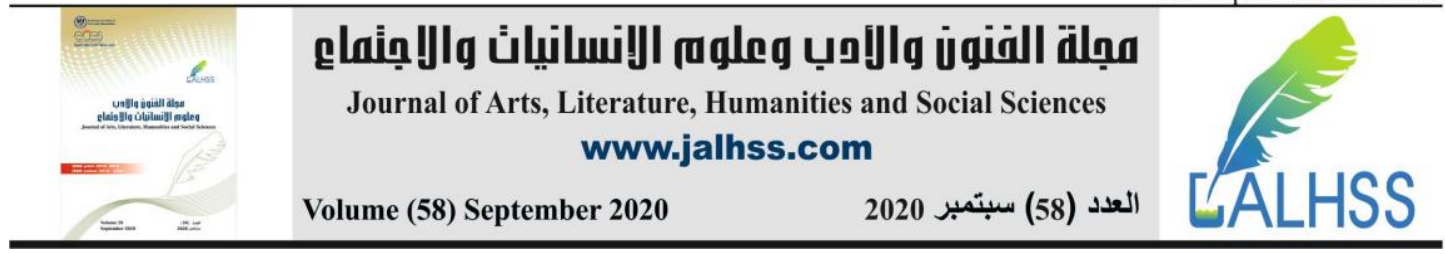

does not sit with him, and who did not see him because of blindness, and comes out with the constraint of "faith" from the Messenger who is a disbeliever, even if he accepted Islam after that if he does not meet him again. what is meant by the words and died on Islam; that is, whoever the Messenger has believed in, then apostatized and died on his response is not also a Companion (Sahabi). As for the one who converted and then returned to Islam before his death, he is considered a companion (Sahabi), whether he meets the Messenger again or not. This definition is used and chosen by investigators. Like al-Bukhari, and his sheikh Ahmad bin Hanbal and those who followed them. (Ibn al-Atheer, Vol. 1, 1997: 8-9; Shaheen, 2003: 11; al-Asqalani, Vol. 1, (no date): 10-13)

The companion (Sahabi), as the audience sees it, is the one who saw the Messenger in the event of the narrator's Islam, even if he did not narrate anything about him. While some do not go to these two views, and see that the Companions (As-Sahaba) are a special sect that deepened their connection to the Messenger, and strengthened their use of it and the lofty principles it brought with it; Delegations that used to come to the Messenger and announce their belief in Islam, and lived in Madinah for a few days, then return to where they came from are not considered members of the Companions (As-Sahaba). Also, the generalization of the word companion (Sahabi) to all those who lived during the era of the Messenger and saw him as a wrong generalization, because many people met the Messenger and believed in his call, but some of them were hypocrites, and others renounced Islam in his life or his death. (Hashem, 1987: 280)

If all the opinions are correct, the last opinion has some directness and can be accepted logically, but we disagree with him on some issues; The hypocrite is definitely not considered among the layers of the Companions (As-Sahaba) because he believed apparently and remained infidel in the interior, while the apostate, who died on his disbelief, as we mentioned above, will automatically lose his advantage as companions (Sahaba).

Without examining the stages of the Islamic call, whether secret or overt, the Prophet began his call in Makkah by order of Allah Almighty; He said: (O thou wrapped up (in the mantle)! Arise and deliver thy warning! And thy Lord do thou magnify! And thy garments keep free from stain! And all abomination shun! Nor expect, in giving, any increase (for thyself)! But, for thy Lord's (Cause), be patient and constant!) (Surah al-Muddathir: 1-7), began the Prophet invited his family first, and then relatives, and the call then secret without knowing the tribe of Quraysh, the number of those who believed in it was forty people, including his wife, Khadija Bint Khuwaylid, Zaid bin Harithah, Ali Ibn Abi Talib, Abu Bakr al-Siddiq, Othman bin Affan, etc., before the migration to Madinah, where he was The Prophet met them in the reefs of Makkah, and when Quraysh knew about them Fought them out; The invitation continued in secret for three years, and then the command came from Allah to speak out. (Ar-Rawwi, 2011: 174-176; At-Tahir, 11-13 Jan. 2013: 13; alMubarakfory, 2007: 75-76)

The Prophet Muhammad was keen on forming the leading personality of the Companions (As-Sahaba) during the secret call, which was mainly based on the qualities of strength and honesty, by adhering to the acts of worship that bring the Muslim closer to Allah, and the Holy Qur'an was the primary reference for the Prophet. Noting that he exerted his efforts in establishing these personalities who assume leadership tasks without looking at any determinants, such as what appeared in the great companion (Sahabi) Ibn Umm Maktoum; Although he was blind, the Prophet used to make him a successor to Madinah when he went out to conquest, and at times he went out to jihad himself. It was reported that he used to say to his companions (Sahaba): "Rise me between the two rows, and bring me the flag, I carry it for you, and I keep it, for I am blind, I cannot escape". He was also one of the Madinah 


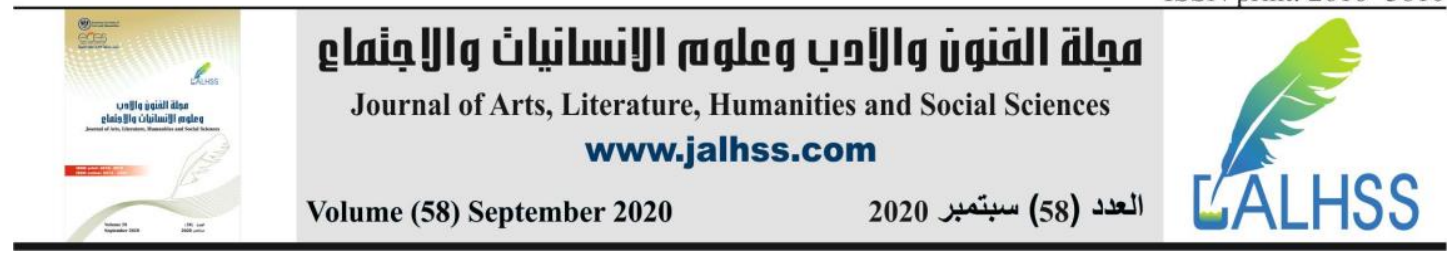

muezzins with the companion (As-Sahabi) Bilal Ibn Rabah al-Habashi (Abyssinian or Ethiopian). (al-Ansari, Jumada I, 1416 AH: 79-84)

\section{The most important controls of the stages of the Prophet Muhammad's call}

The secret phase is considered one of the most important stages of the call (da'wah), and it has a set of controls that have followed the way of the Prophet, the most important of which are: (Ar-Rawwi, 2011: 178-192; al-Selaby, 2006: 99; Ghaloush, 2003: 456)

\section{The jurisprudence of gradualism}

The Prophet is aware of what the da wah should be from being Slow down and patient, and not in a hurry to reach what is required, and it is a rule that all preachers must follow in their call, as the gradual start of the call must be secret, then it will be announced publicly later, but with regard to the length of its secret period It varies according to the circumstances you are going through. Although the Prophet Muhammad was initially called his call secret, but this principle is not conditional in every call, but its existence is determined according to reality in terms of time and place, as Muslims in Makkah followed the approach of considering the call a fixed principle that must be walked on. Although the idea of the confidentiality of the call is related to a gradualism in it, except that abandoning the principle of confidentiality does not mean leaving the graduation in the invitation; Graduation is a rule of Islamic law in all its fields. Examples include: What the Prophet recommended Muath bin Jabal when he sent him to Yemen, where he said to him; "You will come as a people from the people of the scriptures, Call them to the testimony that there is no god but Allah, and I am the Messenger of Allah, if they obeyed so, tell them that Allah assumed them five prayers every day and night, if they obeyed so, tell them that Allah assumed them a handout taken from their rich are reflected in the poor ones, if they obeyed so, beware Precious money dear to its owner, and the Fear of the oppressed, For there is no barrier between it and Allah". (Sahih Muslim, 1991: Vol. 1, The Book of Faith, Chapter Supplication to the Two Testimonies and the Laws of Islam (7), Hadith (29): 50)

\section{Jurisprudence of caution and precaution}

This principle includes the call in its details and all its stages and not only the secret phase thereof, even if the establishment of this principle is in the secret phase, as the Prophet Muhammad taught his companions (Sahaba) to walk on the principle of caution and precaution in all areas of life. As for the call (Da'wah) field, this is evident by the fact that the Prophet chose Dar al-Arqam Ibn Abi al-Arqam, and not others, to call for Islam. The Prophet chose it because the figures were no older than - then - seventeen. Thus, it was not unimaginable for anyone from the Quraysh to have the Prophet in such a house, and the original choice was to choose one of the houses of the great companions (Sahaba) of whom the Quraysh tribe did not dare, as the Dar al-Arqam was far from the centers of the Quraysh communities, in addition to being located on a mountain al-Safa, which facilitated the process of monitoring the roads leading to it, then the figures were from the Bani Makhzum tribe and the Prophet from the Quraysh tribe; There were many conflicts between the two tribes - and at that time - that no one thought that the Prophet would go to the home of any of those tribes. All narrations confirmed that this house was not exposed to any danger during the meeting of the Prophet with his companions (Sahaba).

\section{Jurisprudence of Change}

The change is based on rules that are determined on the basis of society, and the customs of its members, and in Makkah the goal of the Prophet Muhammad was to change his people from idol worship that they found their fathers and grandfathers to worship Allah alone and has no partner. And Allah Almighty has prepared His prophet on that principle within rules. The first of which is changing oneself, as Allah prepared his prophet for calling from his 


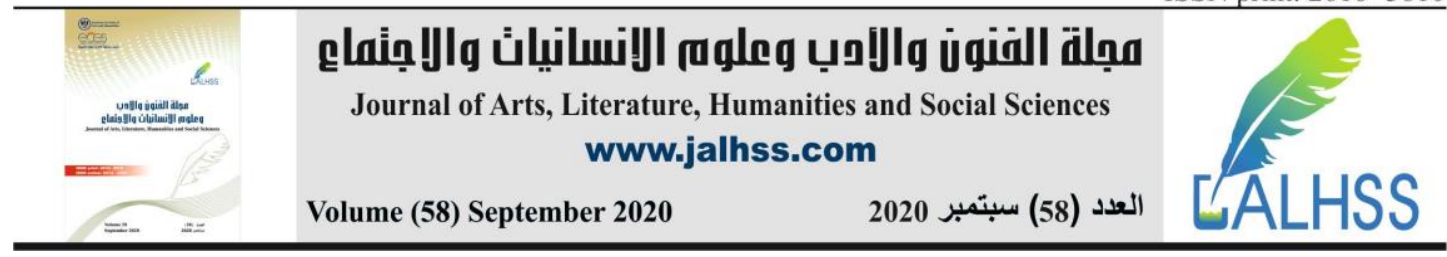

youth. He used to worship in the cave of Hira several nights away from fun and play, and contemplating everything around him, after he was fully prepared for the call (Da`wah), Allah sent Gabriel, peace be upon him to him, and secondly; changing his household, because his wife Khadija was the first to believe in his message, and helped him in his call, then $\mathrm{He}$ moved to the invitation of the people of his house, and their answer had the great effect in supporting him, and the third; the change of society, the Prophet moved to invite members of the Makkan society individually according to what he deems appropriate from their response, then each of them moved to the invitation of the people of his house.

\section{Jurisprudence of Diversity and the Universality of Call (da`wah)}

In his call, the Prophet Muhammad reached all parts of society, from the poor to the rich, from the small to the old ... etc. He did not leave any of the tribes except and reached them and invited them to him, and Islam spread equally among all the tribes, and there was no tribe except in which Islam entered, creating a fertile environment for the spread of the new religion, and not limiting it to a specific class or tribe, just as Islam in its universality was not limited to Arabs and only the people of Makkah; Even the Persians and Romans entered it. It is noted that at this stage the youth of Islam converted to Islam, and this was intended by the Prophet to rely on them to spread his call, besides they had not embraced idol worship for a long time. Therefore; If their acceptance of Islam was faster, just as their age helped perpetuate the call, and the importance and wisdom of the elderly are not hidden, in addition to the fact that the Prophet called both man and woman and did not cancel the role of either of them; The first person to convert to Islam with the Prophet was his wife Khadija Bint Khuwaylid. The woman participated in all the events of the call. She immigrated with him, participated in his conquests, and was subjected to types of torture, as was the case with men like Sumiyaa, the wife of Ammar Ibn Yasir.

\section{Jurisprudence of planning and organization}

It is a principle that the Prophet Muhammad walked in all the stages of the call (da wah), and in everything he was doing, he began to invite those close to him. And the Prophet, while working on this principle, did not leave this principle for the duration of his call, whether secret or overt. In Madinah, he planned to deal with the new situation; So, he put the principle of brotherhood in a regular way, and put the Madinah document, and the treaty with the Jews, in order to organize the administration of the state during that important period ... etc.

\section{Jurisprudence of Counseling}

One of the qualities of the leader is that he does not impose his opinion, but rather consults with those around him who are knowledgeable about what achieves the goal, and the Prophet Muhammad has done this in all stages and positions of the call. Among the most important reasons for the success of his call, he took the opinion of the closest people to him even if it was a woman (i.e. his wife, Khadija Bint Khuwaylid), as mentioned above; In Islam, there is no difference between a male and a female except piety.

\section{The means that the Prophet Muhammad followed in his call}

The Prophet took great care in calling for Islam and he took care of that in Makkah and in Madinah as well, but the call for Islam in Madinah was broader, and the greatest benefit, then the Prophet was interested in establishing mosques after the migration, and made its purposes to be a center for the Islamic call, where he sat and received Coming up to introduce them to Islam, or mediate Muslims to increase their knowledge of their religion, as he used to sit in his home or in the homes of his companions (Sahaba) to teach women. (Shalabi, Vol. 1, 1987: 297)

The life of the Prophet and his method of spreading Islam was a wonderful image of the preacher, and if his life is a measure of behavior for the general Muslim, then it is more 


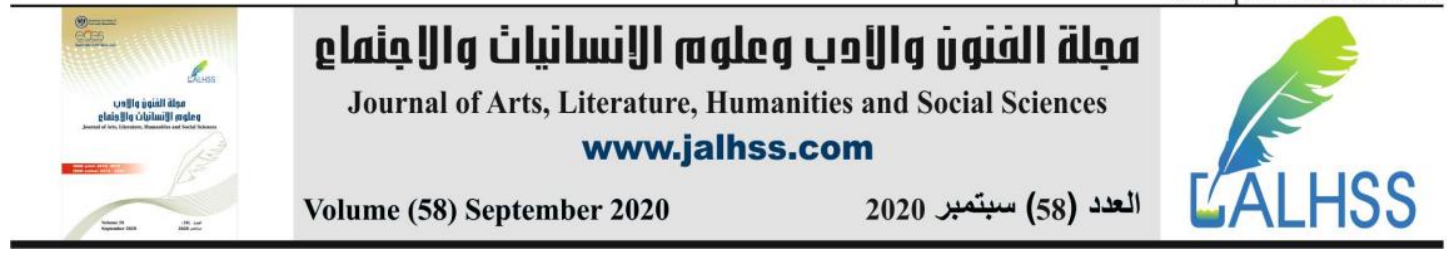

necessary for those working in this field. Obviously, the Prophet began his call in Makkah and met there with great intensity, but he was patient, and he followed in his work steps that are a great example for every preacher. He called for religion secret at first, then took a step forward and called his family and clan, then he reached the top when he declared the call to all people, and he thus guided every preacher not to rush to a step prematurely; Rather, the preacher accompanies people, does not ignore their dimension in the belief about him, and seeks the means to reach their hearts. The means may be by inviting the pure and avoiding cruelty, or by relying on the ties of kinship. If the invitation finds some response on these two paths, he will speak out after he has strengthened his side. (Shalabi, Vol. 1, 1987: 298-299)

The process of communicating Islam needs a number of elements that are necessary to be completed in the required manner, and achieve the desired goals from it, it must make efforts based on evidence of persuasion, and able to arouse the cause of consideration and reflection, and it must by a party that does it whether An individual or group, and it is necessary to diversify in order for the invitation to match the diversity of the people you are heading to. (Ghaloush, 2004: 25)

The Prophet intended to instruct the first generation of Muslims with the types of acts of worship, through: (al-Selaby, 2006: 111)

1. Reflection on the universe of Allah and His creatures, and in the Noble Qur'an.

2. Reflection on the comprehensive knowledge of Allah, and his complete awareness of everything in the universe; Rather, what is in the world of the unseen and the testimony.

3. Worshiping Allah is one of the greatest means of raising the soul and postponing it in a degree. Worship is the goal of humiliating Allah, glory be to Him, and He deserves nothing but Allah alone.

The Prophet Muhammad followed several methods in his call, and among the most important methods of call by which we find the means of confrontation (verbal), and this color of communication depends on the direct confrontation between the caller and the invited, where the message is conveyed by this means, and from the forms of the communication of confrontation (Ghaloush, 2003: 436-438):

1. Simple conversation: it is between a small number of people, including previous knowledge, where each of them speaks with a questioner or respondent; As family members, neighbors ... etc.

2. Discussion: It is one of the arts of education and the call, and it is interchanged between a number of people, as each of them presents their opinion on the subject under discussion.

3. Sermon: It is of all kinds that had a role in ancient civilizations, and the sermon is distinguished by its clear impact because it addresses emotions and emotions, revolves around its subject, and presents many proofs in influential graphic images. The sermon is given only by one speaker. Therefore, the sermon must pay attention to its technical aspects and scientific rules in order to achieve the goal that they hope from behind its work.

4. The symposium: It is based on direct communication, but it differs from the sermon, in which the communication is made with the participation of a number of directions and revolves around one topic.

5. Religious lesson: It is a color of religious contact that often takes place in mosques, and it is a communication in which the topic expands, and opens the way for the listener to question and discuss, and it has a great impact in spreading religion and defining its issues. 


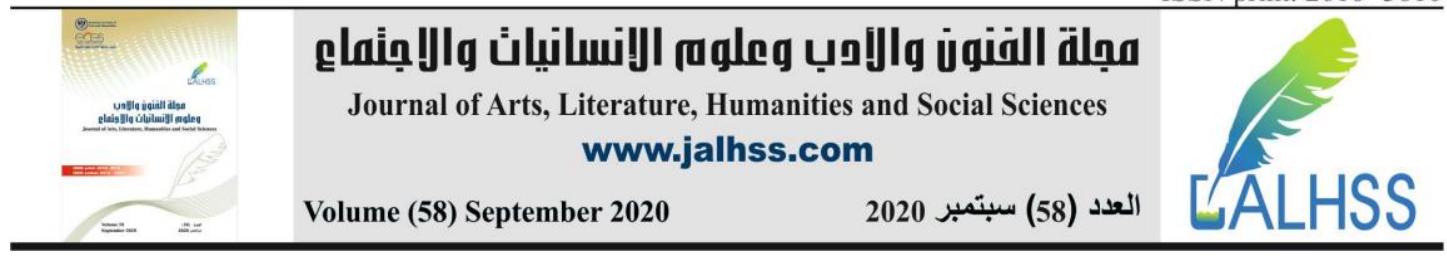

Allah Almighty sent the Prophet, and commanded him to communicate the message of Islam to everyone who can be communicated. So, he resorted to many possible means to achieve the desired goal, and among these means:

1. wisdom and good advice: one of the methods necessary in the call, according to Allah Almighty: (Invite to the way of your Lord with wisdom and good instruction, and argue with them in a way that is best. Indeed, your Lord is most knowing of who has strayed from His way, and $\mathrm{He}$ is most knowing of who is [rightly] guided) (Surah An-Nahl: 125), and to be wise here, to say the building on accurate scientific foundations that include evidence and proofs, in addition to good advice in order to express affection and kindness, and good dealing, then to argue with good things; It is a discussion using good methods. The preacher should employ each of them in the appropriate place for them. He should not be stingy with it, nor use it excessively (Shalabi, 2006: 78-79), as it should be characterized by humility, asceticism, generosity, good manners and payment of illkindness (al-Qahtani, 1421 AH: 961). When the Prophet went to the heart of the Arabian Peninsula, calling for attention, he was concerned with the presidents who are known for his supplication and righteousness, and many of them responded, and their entry into Islam opened the door for the flow of their followers. (Shalabi, Vol. 1, 1987: 302)

2. The individual invitation: The Prophet used to invite those who were distinguished by intelligence and acumen, and they were responding to his call, and they preserved Islam and defended it; Like Abu Bakr Al-Siddiq, Ali Ibn Abi Talib, and Khadija Bint Khuwaylid. This method of call (da'wah) continued throughout the stages, and although its center was in Makkah, it was not interrupted after the emigration.

3. The collective invitation: It was also in Makkah and has many examples, including: The Prophet's call to groups from the Quraish, and his call to the supporters in Aqaba twice, and his meeting with those who converted to Islam in the House of al-Arqam. That image in Madinah also continued to deliver sermons, Homily, etc. The Islamic call in Madinah became two-fold. The first: With Muslims to teach them the obligations of the new religion, and to explain the new legislation that started to flow in the Holy Quran in this era. The second: confrontation with the major blocs in Madinah that had not yet entered Islam, then the trend to call for Islam outside Madinah. In the first part, the Prophet cared for Muslims with great interest to establish the call in their hearts, and to teach them what new legislation, so he extended his sessions in the mosque and Muslims surround him, teaches them and guides them, while they ask him about what he occupies and he answers them and guides them, and he reduced his prayer if he heard the crying of a child behind him, for fear that his mother would be tempted by him Turn away from her prayers. In the second part, which is the invite of non-Muslims to Islam, his policy was extremely impressive and brilliant. He first started in Madinah to secure the new Islamic center, and Madinah there were hypocrites who pretended to enter Islam, and Arabs who clung to their idolatry and Jewish groups; Concerning the hypocrites, the Apostle closed the party to their hypocrisy, and began to court and woo them, until he removed the hypocrisy from the hearts of many of them. As for the pagan Arabs and Jews, they signed a treaty of cooperation between Muslims and non-Muslims, and Muslims secured this life in Medina, and the call became the primary concern of the Prophet after the matter was settled in the new center (Shalabi, Vol. 1, 1987: 300-301).

4. Preaching and remembrance: The Prophet used to take advantage of the situations and places where the Companions (As-Sahaba) were located; He preaches and reminds them, and offers them what is useful for their religion. 


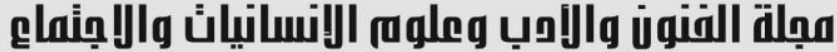 \\ Journal of Arts, Literature, Humanities and Social Sciences www.jalhss.com}
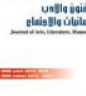

2020

العدد (58) سبتمبر 2020 - (20) - (20)

5. Stories and proverbs: It are one of the most useful means of the invitation, and the most influential on its hearers, as it is characterized by its ease and flexibility. Many stories have been mentioned in the Noble Qur'an, and the Sunnah of the Prophet, as Allah Almighty says: (We do relate unto thee the most beautiful of stories, in that We reveal to thee this (portion of the) Quran: before this, thou too was among those who knew it not). (Surah Yusuf: 3)

6. Sending the Apostles: The Prophet was keen to send companions (Sahaba) who were distinguished by knowledge to the countries to invite people to Islam and teach them their teachings. As sending Mu asib bin Omair to Yathrib (Madinah) before emigration.

7. Writing letters to the kings: This is to invite them and their people to unite Allah, among them: Hercules, the great of the Romans, the Negus, king of Abyssinia, and AlMuqoukis the great of Egypt and others. He chose messengers from among his companions (Sahaba), with knowledge and experience in dealing with diplomatic affairs.

8. Spending money: In order to compose the hearts of Islam, as it was reported that the Prophet used to spend a lot of money for the purpose of the invitation for the unification of Allah, and in that Imam Muslim narrated in his Sahih: "The Messenger of Allah, may Allah bless him and grant him peace, was asked something that he would only give. So, a man came to him and gave him sheep between two mountains (meaning: many), so he returned to his people, and he said: O people: Convert to Islam, because Muhammad gives a gift that does not fear poverty" (Sahih Muslim, vol. 4, The Book of Virtues, Chapter on What the Messenger of Allah, peace and blessings of Allah be upon him, was never asked and he said No (14), Hadith (2312): 1806). Obviously, the Prophet sacrificed for the sake of the call (da'wah) with the effort and money he possessed; Therefore, he mocked the polytheists when they told him: "If you want money, we will collect for you from our money so that you will be the most money, and if you want a sovereign, we make you king" (Ibn Hisham, 1990: 323), but he did not have that goal, and those are the most important characteristics of the preacher; The more the preacher departs from the worldly goods, the deeper the effect and the more successful it is.

\section{E. The characteristics of the Prophet Muhammad as a preacher}

Creating hearts is an essential process in calling to Allah Almighty; Therefore, the preacher must pay attention to this vital aspect of his activity, in order to associate with people in affection and sincerity. Among the features of the personality of the Prophet Muhammad as a preacher, we find the following characteristics. (Shalabi, Vol. 1, 1987: 583-596)

1. Truthfulness: Truthfulness in the preacher is a necessity because what he mentions is not a personal opinion, nor a self-diligence, because he communicates the call of Allah as it was revealed to him, and it shows for its ambiguity, and the transmitter of every statement said about it, and all of this needs to be truthful in reporting, and accurate in the transmission and the statement, Until the invited person is certain that all that the preacher hears is the message of Allah, and that the invitation, as it seemed from his saying, is as it was left by the Prophet, without any increase or diminution. So; For the most important quality of the Prophet is known as "honest and sincere".

2. Honesty: an attribute of honesty; That is why Allah commanded the Muslim not to betray in any aspect, where Allah Almighty said: (O ye that believe! betray not the trust of Allah and the Messenger, nor misappropriate knowingly things entrusted to you). (Surah al-Anfal: 27)

3. merciful: It is an important characteristic that gathered hearts around it, and gave it a great deal of solidity in the face of the most severe and darkest situations, and brought 


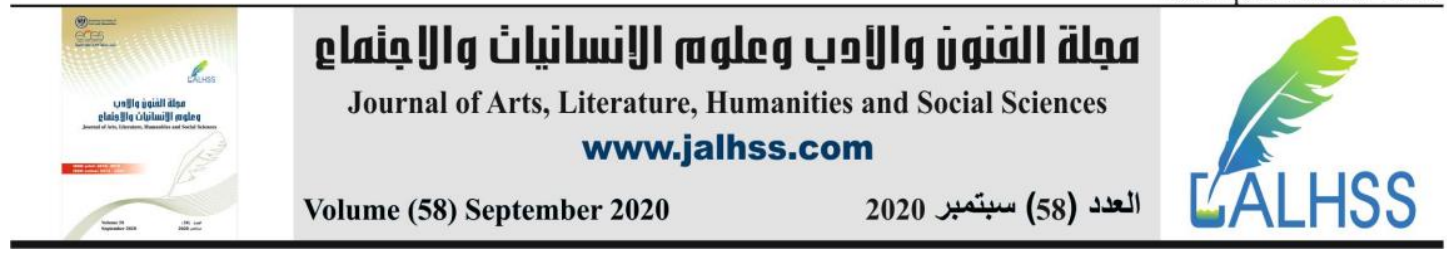

the stranger close to him, and removed hostility from him, because merciful and recklessness are not equal because merciful is the master of morals, as in the Almighty saying: (And not equal are the good deed and the bad. Repel [evil] by that [deed] which is better; and thereupon the one whom between you and him is enmity [will become] as though he was a devoted friend) (Surah Fussilat: 34). A merciful is never a sign of weakness. Rather, it is evidence of strength, and the owner of himself when angry is actually the strong one, and in this the Prophet says: "The strong person is not the good wrestler. Rather, the strong person is the one who controls himself when he is angry" (Sahih Muslim, vol. 4, The Book of Righteousness, Relationship, and Ethics, Chapter Who Owns Himself When Anger (30), Hadith (2609): 2014). And Allah Almighty says: (The recompense for an injury is an injury equal thereto (in degree): but if a person forgives and makes reconciliation, his reward is due from Allah: for (Allah) loveth not those who do wrong) (Surah Ash-Shura: 40). And because of the necessity of this attribute of the preacher, Allah commanded his messenger with it, and he said to him: (Hold to forgiveness; command what is right; But turn away from the ignorant) (Surah al-A'raf: 199), And he said to him: (So forgive them and forgive them. God loves the benefactors) (Surah al-Ma'idah: 13).

4. Humility: It is one of the basic characteristics that helps in good intercourse, because the humble person lives in a destiny. He never appears transcendent, nor is he ever mean, and he feels that authentic equality is the dominant spirit, and in that Allah Almighty says to the Prophet; (And be kind and humble to the believers who follow you) (Surah Ash-Shura: 215). The Prophet did not condone one of his companions (Sahaba); Rather, he sits with them, and defines them as one of them in all affairs of his life, and if he passes by young boys, he stands up and greets them. The Prophet also had good coexistence, tolerance of the soul, and broad ability for dialogue (Shalabi, Vol. 1, 1987: 322 ) to which the Almighty saying applies: (Invite to the way of your Lord with wisdom and good instruction, and argue with them in a way that is best. Indeed). (Surah AnNahl: 125)

5. Conviction and asceticism: sincere asceticism is followed by a conviction of what was given, and chastity from what is in the hands of people, and the generous soul does not stand with its owner at asceticism, conviction and chastity; Rather, it imprinted him with the generous nature given when he finds the one to whom he awaits, no one knows or thanked him because he spent it for Allah's sake, and he does not expect reward except from Allah, and that is only for his belief in the truths of the Qur'an that he recites and guides, and from which Allah Almighty says; (Not upon you (Muhammad) is their guidance, but Allah guides whom He wills. And whatever you spend in good, it is for yourselves, when you spend not except seeking Allah's Countenance. And whatever you spend in good, it will be repaid to you in full, and you shall not be wronged). (Surah alBaqarah: 272)

6. Generosity and generosity: a characteristic of the most important characteristic of the preacher, as it brings close hearts to mind, and paves minds to obedience; Therefore, one of the first moral commands of the Prophet was said by the Almighty: (And do not confer favor to acquire more) (Surah al-Muddathir: 6), that is, do not give more than what was given to people.

7. Equipping scholars and preachers: One of the most remarkable things that sincere and talented leaders do is to educate the second row that takes on them and carries the burden with them and after them; Rather, they bring up successive rows similar to the steps of the ladder, so that society matters are safe from events, so that if a leader dies or 


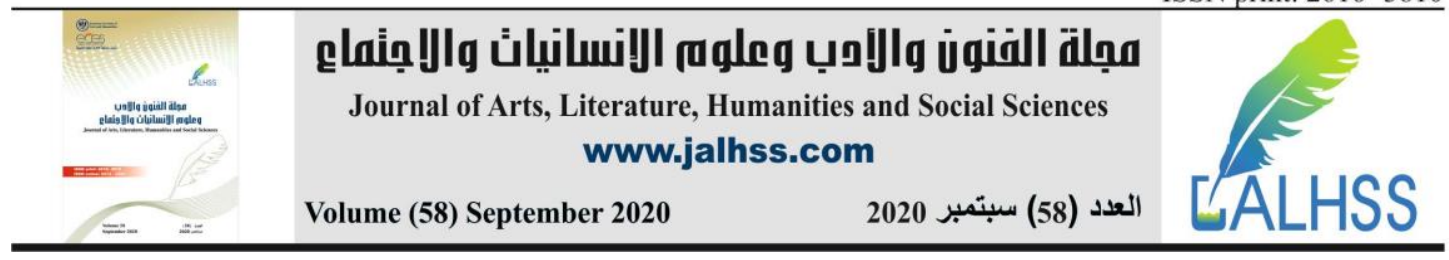

disappears from a cause, his successor appears to bear the burden without stopping or disturbing, Raising the following rows is considered the most important thing for leaders if they have values that they maintain, and goals they seek to achieve. The position of the Prophet on the upbringing of the following rows was exemplary, and it is imperative that Muslims recognize him in order to imitate him and follow his guidance. The Prophet was interested in raising the following rows in various fields. Like the field of knowledge and calling, where the Prophet had a tremendous ability to choose the people who carry the flag of knowledge after him, and they bear the responsibility of communicating knowledge to people, and this is taken from the wisdom and acumen of the Prophet. He was very interested in choosing the right elements that would lead to him with more experiences and knowledge to carry the message of knowledge after him. One of the most prominent characteristics of the campaign of knowledge is the perseverance of research, the capacity of energy, and the desire for intellectual giving. Intellectual what cannot be tolerated by the ideas of others, such as: Ali Ibn Abi Talib, Muath bin Jabal ... etc (Shalabi, Vol. 1, 1987: 304-305).

It is clear to us from the above that the success of the Prophet Muhammad in his call did not come from a vacuum, but rather the result of his exertion of a lot of effort and fatigue. Allah has given him the means and qualities that enabled him to make his call in the best way, and to bring him close to many of his tribe, and among the other tribes of the Arabian Peninsula.

\section{Second: The social reforms carried out by the Prophet Muhammad}

It was not the meaning of the Messenger's migration from Makkah to Madinah, to get rid of discord and ridicule his invitation only; Rather, immigration was a collaboration to create a new society in a safe country. The Messenger, may Allah bless him and grant him peace, settled in Madinah after the Muslims migrated to it from Makkah and from the Arabian Peninsula, and the Messenger became in front of a situation completely different from the situation that was in Makkah. In front of him, the Messenger found a society to which he would give orders, with different elements, the diversity of his doctrines and trends, and the variation of his material and cultural classes. He also found immigrants before him after they left their homes, money and their families, and they came with their faith and their trust in Allah only. They did not have a specific vision in which they lived, or the work they expected, but they came with their poverty, seeking the grace and mercy of Allah, and supporting his call with sincerity (Ghaloush, 2004: 108); They, as Allah said about them: (For the poor emigrants who were expelled from their homes and their properties, seeking bounty from Allah and [His] approval and supporting Allah and His Messenger, [there is also a share]. Those are the truthful) (Surah al-Hashr: 8), they deserve a favor from Allah and His Majesty.

The Prophet Muhammad undertook a number of social reforms in Madinah, after his call succeeded in passing many obstacles during his call in Makkah, and among the most important of these reforms we find:

\section{A. Building the Prophet's Mosque}

The Prophet's first step was to establish the Prophet's Mosque; In the place where his camel stopped, he ordered the construction of this mosque, contributed to building it himself, and built houses next to it, which are the rooms of his wives. The mosque was not only a place for prayers. Rather, it was a university in which Muslims received the teachings and directives of Islam, a forum in which the various tribal elements that had long repudiated pre-Islamic tendencies and their wars consisted of, a foundation for managing all affairs and broadcasting breakthroughs, and a parliament to hold advisory and executive councils, as it was a house in 


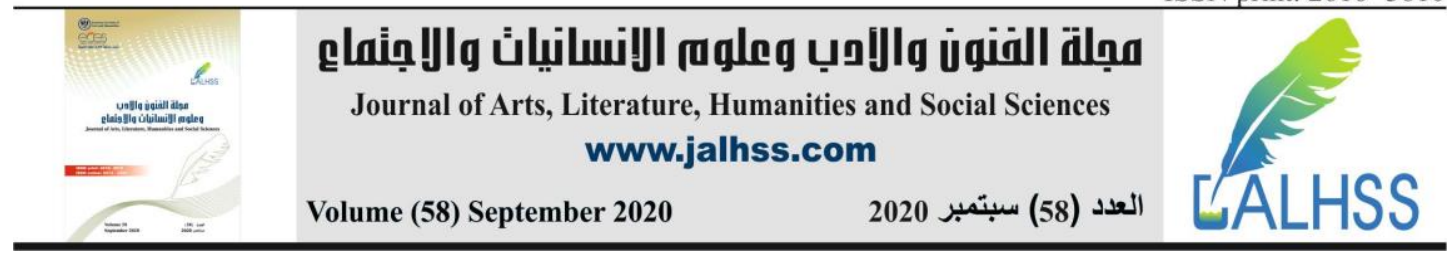

which a large number of poor refugee immigrants who lived There was no home, no money, no family, no children. (al- Mubarakfory, 2007: 184-185)

\section{B. Organizing brotherhood between immigrants and supporters (al-Ansar)}

The Prophet Muhammad devised a system that is considered one of the most remarkable lines of history, which is the brotherhood system in Islam, and made this system the power of brotherhood of lineage, including inheritance. And inheritance continued between them until the noble verse was revealed: (And those who accept Faith subsequently, and adopt exile, and fight for the Faith in your company, - they are of you. But kindred by blood have prior rights against each other in the Book of Allah. Verily Allah is well-acquainted with all things) (Surah al-Anfal: 75). So, he began with this inheritance by lineage and intermarriage, then Allah Almighty made all believers a brotherhood in communion, and the inclusion of the call (Shalabi, Vol. 1, 1987: 283-284), Almighty says: (The believers are but brothers, so make settlement between your brothers. And fear Allah that you may receive mercy). (Surah alHujurat: 10)

The Prophet completed brotherhood between immigrants and al-Ansar, to be interdependent, and brotherhood was not confined to immigrants and al-Ansar only, it was also done between the immigrants themselves; The brother-in-law between him and Ali Ibn Abi Talib in the Prophet's Mosque are both immigrants, and Othman Ibn Affan fraternized with Aws Ibn Thabit. He also performed brotherhood among Muslims whenever a new member entered Islam, or a new immigrant came to Madinah. It appeared that al-Ansar of altruism, and love of good to others. And the immigrants were no less than that in that they returned to al-Ansar all that they gave them when their affairs settled, so the Muslims became a single society in which there is no difference between big and small, rich or poor, or immigrant and al-Ansar, or free and slave; Rather, they were all under the banner of Islam and the leadership of the Prophet, humble to Allah, and worshipers (Ghaloush, 2004: 109-113; Shalabi, Vol. 1, 1987 : 283). And Allah Almighty praised them in many Qur'anic verses, including the Almighty saying: (And they affect themselves, and if they had special characteristics and those who are short of that, say so). (Surah al-Hashr: 9)

The Prophet was trying hard to appear among the members of the Islamic community as one of them, and he did not like to be distinguished from them by anything, so he narrated, "He was with some of his companions on a journey, and they wanted to prepare food, and prepared a sheep, and one of them said: I have to slaughter it, and another said: I have to skin it, Another said: I have to cook it, so the Messenger said: I have to collect firewood. They said: We are enough for you. He said: I have known that you are enough for me, but I hate to be distinguished from you, because Allah hates his servant to see him distinguished among his companions, so he raised and collected the wood" (al- Mubarakfory, 2007: 486). And that is what happened when "the Negus delegation came to the Messenger, so he served them, and his companions said: We are enough for you, O Messenger of Allah, he said: They were generous to our companions, and I love to reward them". (al-Bayhaqi, Vol. 2, 1988: 307)

In Madinah community, the Prophet presented a wonderful example in literature and teaching them valuable values they did not familiarize themselves with before, where he refuses to show any aspect of the Sultan or the rule, and he used to say to his companions: Do not magnify me as the Christians magnified Christ the son of Mary, but I am Abdullah and His Messenger. He once came to his companions (Sahaba), so they stood up to him, and he shouted to them: Do not do as the foreigns do, and let one of you sit where the council ended up with. The Prophet also began raising and cultivating souls; There is a long journey from unbelief to faith, and the Arabs who left idolatry and entered the religion of Islam had to be aware of the dimensions of this journey, and to know the true obligations that faith requires. 


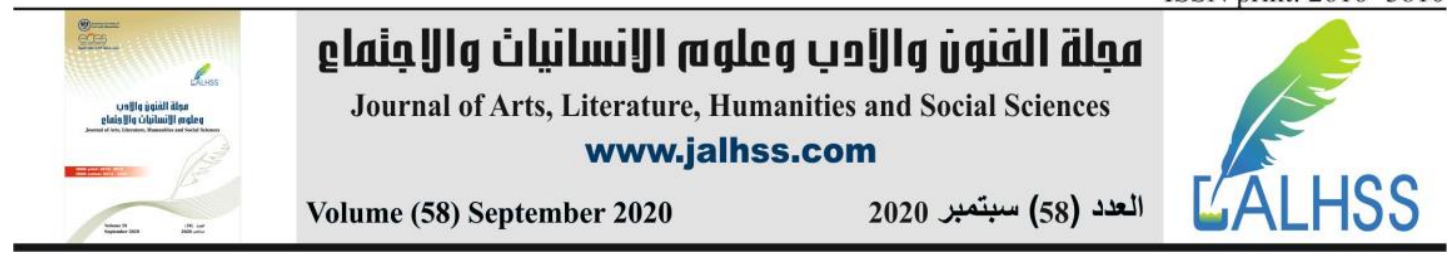

Based on this, the Prophet of Madinah made a great effort to present to Muslims the new etiquette created by Islam, and the noble morals that human society did not have a covenant with. In that, he exerted the utmost effort to rebuild the individual after he entered Islam, as the Prophet worked on two parallel sides; The first aspect is the purification of the Muslim individual from the types of evils and sins that were rampant and for which the imperious soul tends. As for the second aspect; It is the work to gain the Muslim individual the highest qualities and the most generous attributes, and urge them to follow and adhere to them. The Prophet used all the means to raise the Muslim individual, and rebuild it by saying one time and behaving at another time, and the influence of the Prophet with his words and actions was severe for Muslims, and a layer of companions (Sahaba) emerged, highlighting the characteristics of righteousness, and the characteristics of deviation disappeared. (Shalabi, Vol. 1, 1987: 366, 369)

Not only that; Rather, we find the Prophet offers humanity a great form of glorifying the sanctity of the road, building a Muslim individual, and it is a fine type of manners that the Prophet Muhammad offered to cultivate people's morals (Shalabi, Vol. 1, 1987: 372). He forbade sitting on the roads except after fulfilling their right, when he said: "Beware of sitting on the streets, they said, O Messenger of Allah: We do not have our councils to talk about. The Messenger of Allah said: If you reveal nothing but the assembly, then give the way it's right, they said: What is its right? He said: turning a blind eye, ceasing harm, restoring peace, enjoining good and forbidding evil" (Sahih Muslim, vol. 3, The Book of Dress and Adornment, Chapter on the Prohibition of Sitting in the Roads and Giving the Way it's Right (32), Hadith (2121): 1675).

\section{The Madinah document}

The Madinah document came after brotherhood; to organize relations between people in Madinah within written texts that show each of them, what is his and what is it, and set the controls that people follow in their dealings with others inside and outside Madinah. The document represented the first legal constitution in the Islamic state in Madinah, and the document did not leave a tribe of Madinah except for it set a clause and law for it, and organized the relationship between the tribes, and the document also organized the movement of Muslims and others between Makkah and Madinah; Hence, the prophet began to propagate by calling for jihad for the sake of Allah. (Ghaloush, 2004: 118-123)

When the Jews and some Arabs who had not yet converted to Islam lived in Madinah before the migration of the Prophet Muhammed to it, the Prophet wanted to create an atmosphere of cooperation and tolerance between all sects, especially with the Jews who were an important element in Madinah, so he approached them and documented his links with them, and spoke with their superiors And he linked him with them by the bond of affection as they are the people of the Unitarians scripture, which paved the way for a treaty between Muslims and others, so that Madinah becomes a single unit that defends its existence, confronts its enemies, and cooperates fully in it. The summary of the provisions of this treaty is (Shalabi, Vol. 1, 1987: 285-286; Ibn Hisham, Vol. 2, 1990: 143-144):

1. The group has a religious and political personality, and the group has the right to punish the spoiler and to provide the obedient.

2. Religious freedom is guaranteed to all.

3. Madinah's residents, whether Muslim or non-Muslim, must cooperate materially, morally and militarily, and they must respond with support for any attack that may be directed at their city.

4. The Messenger is the supreme head of Madinah's residents, and major issues are presented to him, and pictures of the differences between one sect and another are decided upon. 


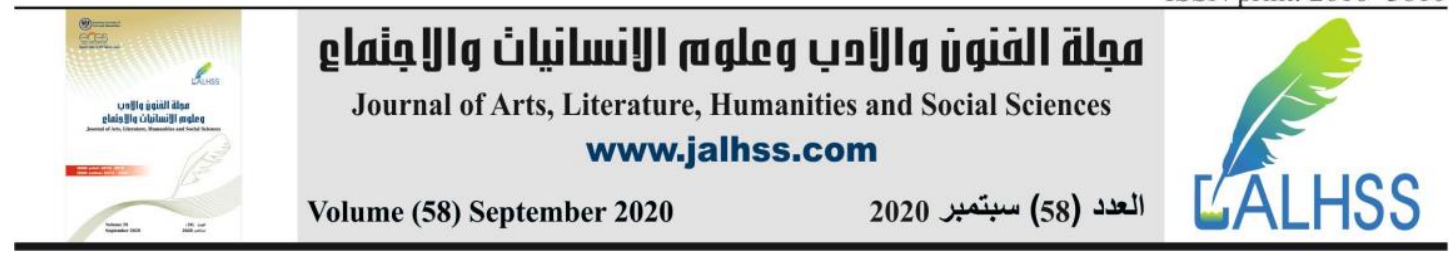

\section{G. Madinah community}

It was not in vain that the Holy Qur'an continued to be revealed to the Prophet thirteen years in Makkah, establishing the doctrine of monotheism, and masterminded the entire call (Da wah) movement at this stage on its axis, directing the esteemed companions (Sahaba) on their basis. The Prophet was working to establish the first Islamic group, in order to understand and cultivate the doctrine of "There is no god but Allah" with all its conceptual and behavioral connotations. And from here; His endeavor to connect believers with Allah through the Noble Qur'an was an educational approach that he needed until the end of his life. Indeed, the Madinah's era is not a continuation of the monotheistic, doctrinal approach, despite the legislative nature of the Madinah's Quranic surahs. (al-Ansari, Jumada I, 1416 AH: 69)

The features of the Muslim community were formed and became an example of all the good, including goodness, freedom from corruption, loss, poverty, and weakness. The Prophet applied the terms of the document in practice, and not only made it items, but the Muslim personality was formed according to the ethics and behavior it contained. Among the most important elements upon which society is based is the perfection of religion; The call in Makkah was based on building a sound faith in order to build the Muslim community. Behavior depends on beliefs. That is why the Prophet began to believe until the souls of Muslims were assured, and faith became certain within them, then the provisions of the Shariah gradually descended upon them according to the events that occurred, so they would not have responded to what was revealed to them, and applied it without any doubt or hesitation. It is clear from the verses of the Noble Qur'an that orders and prohibitions were not repeated frequently, as they were applied as soon as they were brought down, and the Prophet was the reference in guidance and inquiries، and the Muslims remained in this state until the religion was completed (Ghaloush, 2004: 204-206; Al- Mubarakfory, 2007: 188). Allah Almighty said: (This day have I perfected your religion for you, completed My favour upon you, and have chosen for you Islam as your religion). (Surah al-Ma'idah: 3)

The Prophet was faithful in reporting, and keen on the arrival of Islam to the people, sad about their departure from it, and keen on his companions (Sahaba) to cause them any harm, as he did not concede to implement the limits of Allah. The Prophet said: "O people: the people before you were destroyed, that if the sheriff stole them, they would leave him. and if the weak stole them, they would put an end to it. If Fatima Bint Muhammad had been stolen, her hand would be cut off" (Sahih Muslim, vol. 3, Book of al-Hudood, Chapter on cutting the hand of the thief and forbidding intercession in the boundaries, hadith (1688): 1315). Thus, the Muslim community in Madinah changed his conditions at all levels, as the Companions (Sahaba) received change in faith, trust, and action; they performed orders, and they avoided the prohibitions with love and contentment (Ghaloush, 2004: 210-212).

The Companions (Sahaba) did not pay any attention to what was revealed to them by revelation; Rather, they were satisfied with their full debt, which is not lacking. Madinah community believed in its faith in Allah, and its members presented a correct image of Islam, and they began to receive the teachings of Allah Almighty that the revelation received correctly. They were concerned with the Holy Qur'an and the Sunnah of the Prophet in keeping and understanding, and surrounding everything that comes down, and they know the guidance and rulings it carries, and if they lacked meaning they asked the Prophet about it, and they were receiving what comes to them from the revelation of work, application and implementation. By doing so, they were a practical picture of the revealed revelation, permitted its lawfulness, and forbade it forbidding it with accuracy and sincerity. And it was from their sincerity with the teachings of Allah that they offered what they did not take from 


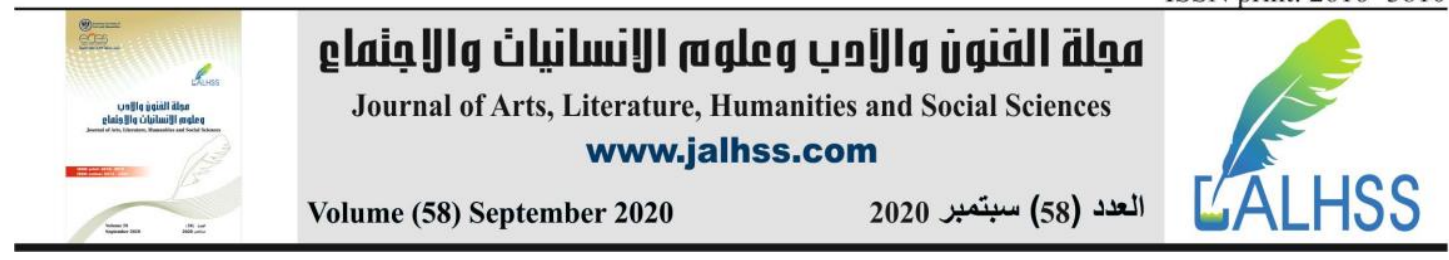

the inheritance of Persia or the Romans, even if it converged in some of its parts with the teachings of Allah.

The Prophet laid the foundations for dealing with others within society in order to achieve the interests of all, and thus the message of Islam was an example to be followed in all fields, and all institutions within the state turned into institutions of a legal nature; Like the Quba Mosque and the Prophet's Mosque, which was the center of the Muslim movement; In it worship is performed, tribes and delegations are received, and from it armies are launched, Once the laws concerning the Dhimmis (people under protection) were established in it. By doing so (Ghaloush, 2004: 212-222), The Muslim community, and its features have emerged, and deserved to come down in describing the verse: (You are the best nation produced as an example] for mankind. You enjoin what is right and forbid what is wrong and believe in Allah. If only the People of the Scripture had believed, it would have been better for them. Among them are believers, but most of them are defiantly disobedient). (Surah Aali-Imran: 110)

The Prophet made a great effort to guide the formation of the family community, which is the small community whose units form the larger community. The Prophet pays great attention to the family community, urging attention to choosing the righteous wife, then urging care for children and justice among them in giving and treating, and he went on to talk about explaining the rights of both husband and wife to the other' He explained the Symbiosis between parents and children, and obliged the children to take care of the parents even with the difference in religion. (Shalabi, Vol. 1, 1987: 375)

In building the Islamic community, the Prophet Muhammad went in a broader direction, drawing lines to form among them the greatest society known to mankind, and these lines included organizing the link between the ruler and the ruled, explaining the economic system that highlights the obligations of the rich and the rights of the poor, and stresses the need to implement the Islamic legislation that was celebrated during the Madinah period . Besides these great foundations, the Prophet was seeking means to make every person feel that he is a part of this Islamic society, that he should work to make him happy and uplifted, and that the individual does not achieve success for himself except with the success of his community (Shalabi, Vol. 1, 1987: 375-376). The Prophet said: "None of you believes until he loves for his brother what he loves for himself". (Sahih al-Bukhari, 2002, Book of Faith, Chapter of Faith That Loves to His Brother What He Loves for Himself, Hadith (13): 13-14)

While in Madinah, the Prophet deliberately raised the governors and rulers. After the Islamic State expanded and was about to include the entire Arabian Peninsula, he went to raise the governors over the provinces during his reign, and to raise the rulers after him, and the pattern that the Prophet was keen on was consistent with his saying: "Two types of people if They were righteous, the people were reformed, and if they were corrupted, the people were corrupted. Who were they said? He said: Kings and scholars" (al-Jawziyyah, Vol. 2, Rajab 1423 HD: 16). The Prophet was aware of the importance of the ruler in relation to the parish, so if he was good, his best choice was his assistants, and his assistants thus bested their behavior with the parish, then matters stabilized and people were happy. On the contrary, the corrupt ruler is. (Shalabi, Vol. 1, 1987: 396)

The Prophet Muhammad gave great attention to education, as he saw education has taken its new form, i.e. communicating and learning science. so, the Prophet sought to urge that, and he surrounded it with a set of controls and directives so that the scientific form does not distract from its purely educational intent, and its authentic monotheistic content, giving priority to that For the Holy Qur'an to memorize and understand it (al-Ansari, Jumada I, 1416 AH: 105), and in that the Prophet says: "It is better for you to learn and teach the Qur'an" 


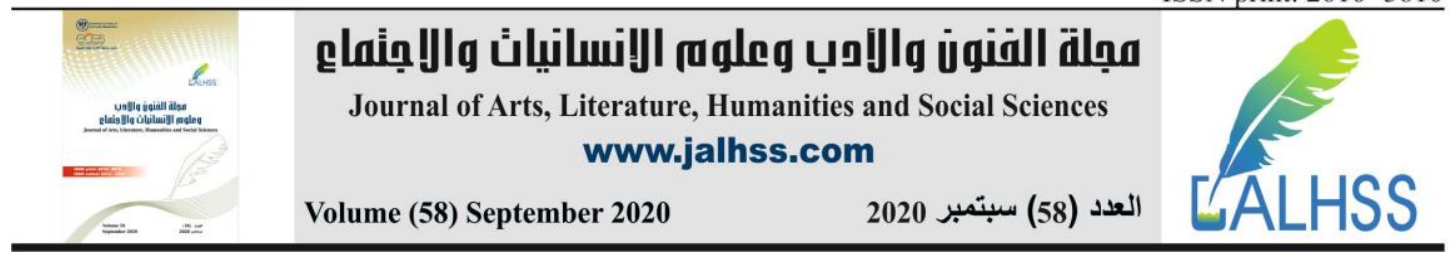

(Sahih al-Bukhari, Book of the Virtues of the Qur'an, Chapter on Your Best in Learning and Teaching the Qur'an, Hadith (5027): 1283-1284). Then he says about his Sunnah: “Allah's victory is a believer who hears my essay. then tell her about me, so maybe a carrier jurisprudence is not a jurist، and a carrier of jurisprudence to the one who is more aware of it". (al-Albany, Vol. 1, 1997, Hadith (188-229): 94)

\section{Jihad}

Allah Almighty has initiated jihad through many stages, and the following is mentioned:

1. The stage of endurance and patience: This stage was in Makkah before the immigration of Muslims to Madinah, and Allah commanded the Muslims to be patient, because of their inability to respond to aggression and confrontation, in addition to that their number was few compared to the number of polytheists; That is why it was required of them only patience, and to ensure the religion of sedition, so that each of them exert their efforts on themselves. Many Quranic verses were received calling for and urging endurance and patience with the mischief of the polytheists, including: the Almighty saying; (And be patient with what they say, and keep away from them in a good) (Surah al-Muzammil: 10), and the Almighty said; (Hold to forgiveness; command what is right; But turn away from the ignorant) (Surah al-A'raf: 199). Although the verses were a letter addressed to the Prophet, the matter of the Prophet is considered an order of his nation The Muslims were encouraged by this knowledge that Allah Almighty defends them, and despite the abandonment of the fighting, this was an investigation of the lesser harm to the right of Muslims, and it was established in effect, and it is one of the fixed and established types of jihad.

2. The stage of permission to fight: This stage came after the migration of Muslims from Makkah to Madinah; The era of Islam in Makkah did not need military power, as the permission to fight had not yet come, but Madinah's era was full of conflict, where Allah Almighty revealed his saying: (Permission is given to those who fight because they were wronged. Allah has power to grant them victory) (Surah al-Hajj: 39), and that Allah knows. Allah authorized the Muslims to fight after all the suffering they suffered from the polytheists before their migration, which led them to leave Makkah, leaving behind everything they possessed, and while they were harmed, they came to the Prophet complaining to him, and he told them every time that he had not been authorized to fight yet, And that is until the pledge of allegiance to the second obstacle, as it included the agreement of the Prophet with those who pledged allegiance to him to support him and defend him; This indicates the proximity of the permission for jihad and fighting legislation. When the Muslims migrated, their power began to appear, and they were authorized to fight, which was at the beginning of the form of invasions and companies, and all of this was before the Battle of Badr, and in this the Prophet says: "The gates of Paradise are under the shadows of swords" (Sahih Muslim, vol. 3, Book of the Principality, Chapter Proof of Heaven for the Martyr (41), Hadith (1902): 1511). The Prophet also took a keen interest in organizing the army, which included the army's march and order، and if the army faced the enemy, the Prophet divided it into a heart, a right and a left.

It is worth noting that the first thing that the Prophet cared about was the call to power that takes health as a basis for it, and one of his hadiths in the call to force is the saying: "A strong believer is good and more beloved to Allah than a weak believer". (Sahih Muslim, vol. 4, Book of Destiny, chapter on commanding force and leaving impotence (8), hadith (2664): 2052) The force is obligated to perform the duty, the accuracy of work, and to maintain the integrity of the family and the state. (Shalabi, Vol. 1, 1987: 419-420) 


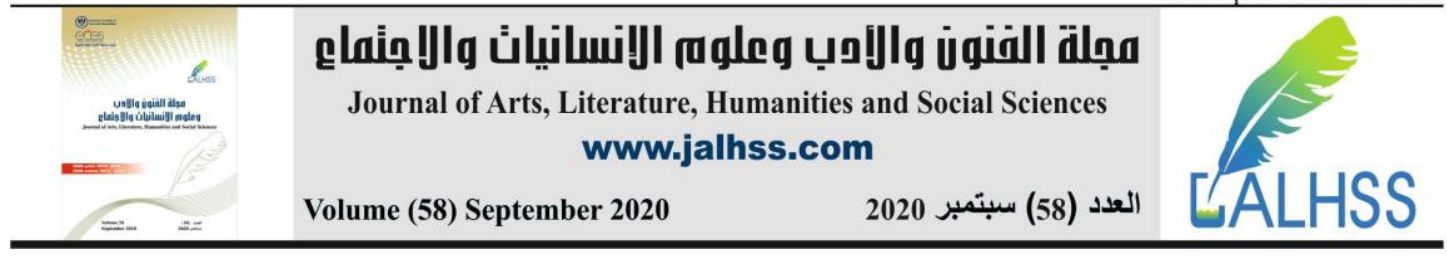

It is worth noting that only those immigrants and al-Ansar participated in these invasions and companies، and in that Allah Almighty says: (Fight in the way of Allah those who fight you but do not transgress. Indeed. Allah does not like transgressors) (Surah al-Baqarah: 190). Permission to fight differs from commanding it, fighting requires patience, and going out to fight is also optional; When Muslims went out with the Prophet to Badr, their exodus was voluntary, and out of love for jihad. Therefore; The Prophet was keen to consult al-Ansar in going out to the fighting, and at this stage also began preparing for the third stage by forbidding the withdrawal from the battle, and ordering persistence in it, intensity in the confrontation, confidence in the victory of Allah, and equipping the strength of the army and horses. (Ghaloush, 2004: 235-238)

From the foregoing, it is evident that the Prophet Muhammad after his emigration and his companions (Sahaba) to Madinah succeeded in achieving success in establishing the Islamic State, and melted all the elements of Muslims in their crucible, and he was faithful in communicating his call, and was keen on the arrival of Islam to all people. And the Apostle planted in Muslims the highest verses of education and etiquette, in order to make from them and those who will come after them a strong generation of faith in Allah and in the knowledge through which they were able to master a large part of the world for a period of time. The Prophet also managed to unite Madinah's residents, Muslims and non-Muslims, under his presidency, after he built the Prophet's Mosque, which served as a beacon to receive religious sciences, and a university to refine the morals and societal values that Arabs and non-Arabs were missing before the emergence of Islam.

\section{Conclusions}

At the conclusion of this study, it is possible to stop at some important results, including:

1. That the Arabs and other neighboring peoples were living a life full of various avenues of political, religious, moral, and social corruption, which paved the way later - for the success of the Islamic call that was revealed to the Prophet Muhammad.

2. The Prophet, in spite of the persecution and harm he suffered from the polytheists of his tribe, Quraysh, except that thanks to his wonderful style of calling, he succeeded in attracting many of the supervisors of the residents of Makkah, in addition to the slaves who were lacking the lowest elements of humanity among their polytheists.

3. The Prophet was very successful in his call through a set of controls that he followed, the most important of which are: the jurisprudence of gradualism, the jurisprudence of caution and precaution, the jurisprudence of change, the jurisprudence of diversity, the universality of call, the jurisprudence of planning and organization, and the jurisprudence of counseling.

4. The life of the Prophet, his means, and his method of spreading Islam were a wonderful image of the preacher, as he began his call in Makkah and met with great intensity, but he was patient, and he followed in his work steps that are a great example for every preacher. He called his call secretly, then he made a step forward, then he invited his family and his clan, then he reached the top when he declared the call to all people, and he was thus guiding every caller not to rush to a step prematurely.

5. The success of the Prophet Muhammad in his call did not come from a vacuum, but rather as a result of his exertion of a lot of effort and fatigue. Allah loved him with the means and qualities that enabled him to make his call in the best way, and to bring him close to many of his tribe, and among the other tribes of the Arabian Peninsula. 


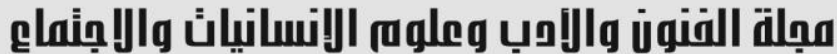 \\ Journal of Arts, Literature, Humanities and Social Sciences www.jalhss.com \\ Volume (58) September 2020 \\ العدد (58) سبتمبر 2020}

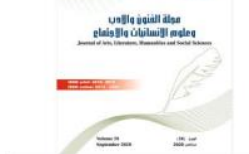

6. The Prophet Muhammad, after his migration to Madinah, had great success in establishing the first Islamic state, and he was able to melt all the elements of the Muslims in his crucible, and he was faithful in communicating his call, and was keen on the arrival of Islam to all people.

7. The Prophet planted in Muslims the highest verses of education and etiquette, in order to make from them and those who will come after them a strong generation of faith in Allah and in the knowledge through which they were able to master a large part of the world for a time.

8. The Prophet managed to unite Madinah residents, both Muslims and non-Muslims, under his presidency, after he built the Prophet's Mosque, which served as a beacon to receive religious sciences, and a university to refine the morals and societal values that Arabs and non-Arabs lacked before Islam.

\section{References}

\section{First: The Holy Quran.}

\section{Second: The hadiths}

1. Al-Albany (Muhammad Nasir al-Din) (1997), Sahih Sunna Ibn Maja, Vol. 1, Riyadh: Al-Ma'aref Library for Publishing and Distribution.

2. $\quad$ Sahih Al-Bukhari (2002), 1st edit., Damascus-Beirut: Dar Ibn Katheer.

3. Sahih Muslim (1991), Vols. 1, 3. 4, Cairo: The Arab Books Revival House.

\section{Third: Initial references}

4. Al-Asqalani (Ibn Hajar) (no date.), Injury in Distinguishing Companions (Sahaba), Vol. 1, Beirut: The Arab Book House.

5. Al-Bayhaqi (Abu Bakr Ahmed bin Al-Hussein) (1988), Evidence of Prophethood and Knowledge of the Status of the Owner of the Law, Vol. 2, Cairo: Dar Al-Rayyan Heritage.

6. Al-Jawziyyah (Ibn Qayyim) (Rajab 1423 AH), Informing the Signatories on the Lord of the Worlds, Vol. 2, I ${ }^{\text {st }}$ edit., Dammam: Ibn Al-Jawzi House.

7. Ibn Al-Atheer (Ali bin Muhammad al-Jazari) (1997), lions of the forest in the knowledge of the companions (As-Sahaba), investigation: Sheikh Khalil Mamoun Shiha, Vol. 1, ${ }^{\text {st }}$ edit., Beirut: Dar Al-Marefa.

8. Ibn Hisham (1990), Biography of the Prophet, Vol. 2. Comment on it and output its hadiths: Dr. Omar Abdel Salam Tadmouri, Beirut, Arab Book House.

\section{Fourth: Secondary references}

9. Ahmad (Muhammad Helmi Muhammad) (1977), The Caliphate and the State in the Umayyad Period, Cairo: Youth Library.

10. Al-Adawi (Ibrahim) (1987-1988), The Umayyad Empire, Cairo: Youth Library.

11. Al-Ansari (Farid) (Jumada al-Awwal 1416 AH), Tawheed and Mediation in Da`wah Education, Kitab al-Umma, Vol. 1, No. 47, Year 15, Doha: Ministry of Endowments and Islamic Affairs in Qatar.

12. Al-Bayanouni (Muhammad Abul-Fath) (2010), Introduction to the Science of Da`wah, $3^{\text {rd }}$ edition, Beirut: The Resala Foundation.

13. Al-Mubarakfory, Safi al-Rahman (2007), The Sealed Nectar, Doha: Ministry of Endowments and Islamic Affairs. 


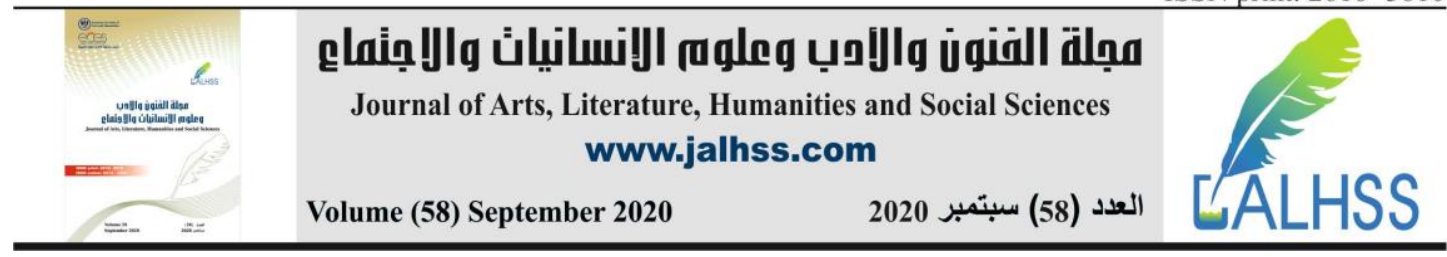

14. Al-Qahtani (Saeed Ibn Ali) (1421 AH), Jurisprudence of Da`wah in Sahih al-Imam al-Bukhari, Vol. 2, Riyadh: Publications of the Ministry of Islamic Affairs, Endowments, Da`wah and Guidance.

15. Al-Qaradawi (Youssof) (1996), al-Da'ia Culture, $10^{\text {th }}$ edition, Cairo: Wahba Library. 16. Al- Selaby (Ali Muhammad) (2006), The Biography of the Prophet, Presenting facts and analysis of events, $3^{\text {rd }}$ edition, Beirut: Dar Al-Maarifah.

17. Ghaloush (Ahmad Ahmad) (2004), The Origins of the Islamic Call, 1 st edition, Cairo: Al Resala Publishers Foundation.

18. Ghaloush (Ahmad Ahmad) (2003), The Biography of the Prophet and Propagation in the Makkan Covenant, 1st floor, Cairo: The Resala Foundation.

19. Ghaloush (Ahmad Ahmad) (2004), The Biography of the Prophet and Propagation in the Civil Testament, $1^{\text {st }}$ edition, Cairo: Al Resala Foundation for Printing, Publishing and Distribution.

20. Shaheen (Atef Saber) (2003), Men and Women around the Messenger, $1^{\text {st }}$ edit., Mansoura: Dar Al-Ghad Al-Jaded.

21. Shalabi (Ahmed) (1987), Encyclopedia of Islamic History and Islamic Civilization, Vols. 1, 2, $12^{\text {th }}$ Edition, Cairo: The Egyptian Renaissance Library.

22. Shalabi (Abdul-Ati) (2006), Islamic Oratory, Alexandria: The Modern University Office.

23. Hashem (Ahmed Omar) (1987), The Rules of the Origins of Hadith, Cairo: Institute of Islamic Studies publication.

\section{Fifth: scientific periodicals and conferences}

24. Al-Rawwi (Salahuddin Namiq) (2011), "The Secret Call and Jurisprudence", Journal of Islamic Sciences, College of Sharia, University of Iraq, No. 3, Iraq.

25. Al-Zaki (Aladdin) (June 2008), "The Means of Propagation between Authenticity and Modernity", Khartoum: Al-Da`wah Magazine, The Center for Da`wah, World University of Africa, No. 16.

26. At-Taher (Amin Muhammad) (January 11-12, 2013), "The Phases of Da`wah and its Role in Achieving the Purposes of Sharia", The First International Conference on the Prophet's Biography, Book One, Khartoum: World University of Africa. 